\title{
The Role of Class Teachers in The Implementation of Guidance and Counseling in The Formation of Characters in Children with Special Needs
}

\author{
Lia Mareza \\ \{liamareza@ump.ac.id\} \\ Universitas Muhammadiyah Purwokerto, Purwokerto, Indonesia
}

\begin{abstract}
This research was conducted at SDLB B Kranji. This study aims to determine classroom teachers' role in implementing counseling guidance services in character building for students with special needs at SDLB B Kranji. Research to be conducted by researchers using qualitative research. The data validity used triangulation. Data collection techniques using observation, interviews, and documents. Triangulation testing used by researchers is a triangulation of sources and triangulation of methods. The results showed that teachers at SDLB B Kranji did their role well, namely classroom teachers, to implement counseling guidance services and foster self-confidence, discipline, and achievement motivation to have good character. Implementation of counseling services using individual and classical guidance. Service users' forms are support and responsiveness services, personal counseling services, and group guidance services. The result is that teachers provide counseling guidance services through the provision of rewards, habituation, and punishment if necessary to instill good habits so that students with special needs can behave and act based on the values that have become their personalities.
\end{abstract}

Keywords: counseling, character education, children with special needs.

\section{Introduction}

Education is an essential thing for every individual because education provides knowledge and teaches how to behave appropriately. Education fosters students into mature individuals, individuals who can design the future and make the right decisions in life to develop their potential to become better at achieving predetermined goals. Character education is a form of human activity in which there is an educational action intended for the next generation. The teacher's character building is significant for elementary school students, especially students with special needs. One of the critical stages that must be considered is primary education, which becomes a solid foundation for development at the next step and the formation of understanding, attitudes, and lifelong learning behavior (long life learning). [1] states that building the Nation's character through education must be followed up with a continuous and systematic program. They are starting from cognitive value recognition, affective value appreciation to real value practice. [2] revealed that character education is a conscious effort made by teachers to students who teach and shape good morals, ethics, attitudes, motivation, behavior, skills, and a sense of culture and noble character so that it fosters student abilities to give good and bad decisions and 
to bring goodness into everyday life. Implementing character education in regular schools is not much different from implementing inclusive schools or special schools. The difference lies in students with special needs in the class and the way teachers instill character values in all students with special needs.

[3] explains that character development has a particular purpose for an education system. According to [4], character planting can erode the negative attitudes that a person often carries out. Through education, knowledge is achieved, but skills and attitude become a goal and assessment. In this case, it can also be social skills in children with special needs. [5] argues that adults' guidance is carried out to children to provide teaching, moral improvement, and academic training. Developing the potential for students with special needs through the teacher's affective learning process, one of which is to form character in students. [6] explains that name is the typical good values (knowing the importance of kindness, wanting to do good, having a perfect life, and having a good impact on the environment) embedded in oneself and manifest in behavior.

Characters formed, such as self-confidence, discipline, and achievement motivation will develop student learning achievement. In the initial interview with the school, the basic things that become the basis for developing student achievement with special needs start from building self-confidence and the desire to be disciplined and motivated to achieve. The learning process requires an explanation that will encourage individuals to do work. [7] states that learning includes habits, skills, attitudes, understanding, interests, appreciation, and self-adjustment. The teacher has a role in growing and motivating students. [8] stated that motivation is defined as students' tendency to carry out learning activities encouraged by the desire to achieve good achievement and learning outcomes. Cultivating good character will foster achievement motivation in students as well. [9] stated that achievement motivation is the desire to experience success and participate in activities; success depends on one's efforts and abilities. An individual who has learning motivation can be seen when learning takes place, including students paying attention to the teacher who is explaining the learning material, students want to do assignments, and students want to do homework given by the teacher and carry out student assignments or obligations in a disciplined manner. School rules and operational support programs in schools are also proven to be able to improve discipline both in school attendance, how to dress, how to behave, a sense of responsibility for their obligations, study diligently illustrates good characteristics of students and reduces harmful activities such as tantrums, insecurity. or not concentrating. [10] explains that school discipline supports the creation of student disciplinary attitudes because they contain requirements that must be implemented by students and prohibitions that must not be implemented. [11] explains that the role of classroom teachers is also a counseling teacher in elementary schools, namely that teachers must be able to understand the characteristics and abilities of each student, help students solve problems, teach the ability to behave and have social relations, help students develop discipline learning to increase the learning achievement of students with special needs.

Achievements in learning that are owned can be built through the student's self-confidence. [12] explains that self-confidence is part of one's cognition that influences one's decisionmaking to organize and organize actions to achieve the results someone wants. This personality aspect is in the form of a person's high self-confidence and abilities. [13] said that someone who has self-confidence would neutralize the tension that occurs in him to face the problems he is experiencing. When children with special needs can regulate negative emotions so that students can focus on their learning, according to [14], it explains that if an individual has high confidence, he will get an assessment of his / her abilities and the individual's process can feel merit to succeed. [15] argues that students' self-confidence will affect the results, namely 
learning achievement in both academic and non-academic fields. This is because it is not only in the knowledge aspect but also in the non-academic aspects of students with special needs who can excel in one particular field. [14] explains that good student self-confidence will affect academic and non-academic quality with teachers' role in learning and parents. This involves students to feel proud of themselves so that it triggers to increase their self-confidence and develop themselves based on self-confidence.

Based on interviews with the Principal of SDLB B Kranji, the character planting program in students has been implemented well. The teacher does this by providing guidance and counseling services to students that are carried out classically when learning occurs and individually between students and teachers; even the principal also participates in the guidance and counseling. Teachers' role in providing advice and counseling services can offer enormous changes to students with special needs so that students' character is well-formed with the embedded value of character education.

\section{Methods}

The research method used in this research is descriptive qualitative because it aims to describe teachers' role in the implementation of guidance and counseling services in character building for students with special needs. The goal is to find out the part of teachers in the performance of guidance and counseling services in character building for special needs students. The research subject is any participant who can provide information related to the research objectives. The matter's role is to give responses and data about the researcher's data and give input to the researcher, either directly or indirectly. Researchers chose research subjects, namely class teachers and students with high-class special needs. There are 1 class teacher, the principal, and eight students with special needs. Data collection was collected using observation, document recording, and interviews. Documents used include teacher books, student books. The interview method was carried out by extracting information from sources (class teachers, school principals, students) about guidance and counseling services in character building.

\section{Results}

Counseling guidance in elementary schools is essential for a classroom teacher. Services in guidance and counseling will run smoothly if a teacher understands students' characteristics to achieve the desired goals. Guidance is provided to all students so that there is no jealousy between students with special needs. The teacher approaches students to find the source of the problem so that it can be overcome.

\subsection{The Role of Class Teachers in the Implementation of Guidance and Counseling in Building Confidence Character}

Not all students with special needs have self-confidence, even though some are overconfident. However, from the results of observations and interviews, it was found that students with special needs had doubts, tended to avoid, lack of self-initiative, were easily anxious, had low self-confidence, lacked enthusiasm, and lacked the courage to appear in front of a crowd. 
Therefore, the school provides group and individual counseling guidance services that are carried out regularly. The school also includes teaching aids and a place to practice to improve their reasoning skills, thinking skills, and physical abilities to be further enhanced by showing self-confidence. [16]

Counseling guidance services are carried out in groups and individually. The implementation of counseling guidance services carried out by classroom teachers, namely responsive services and support services. Guidance and counseling will be carried out on Saturdays. Although it does not rule out, it can be carried out situational depending on students' condition at that time. The teacher said that the implementation of guidance services in groups was to help other students who were less confident, so they did not dare to ask questions, so they did not understand the material. Peer tutors are applied by teachers, have a good impact on students. The results obtained were that students were able to volunteer to answer questions on the blackboard and ask the teacher about material that had not been understood. Following the opinion of [17], guidance can be interpreted as a process of assisting individuals to achieve the understanding and self-direction needed to make maximum adjustments to schools, families, and communities to apply these adjustments in their daily life.

Teachers conduct individual counseling services personally with students in separate offices or rooms. According to the counseling guidance plan, the teacher provides counseling to students by advising them to change their attitude to be more confident. The teacher also provides rewards in learning activities to increase students' self-confidence. The teacher motivates by using various ways so that students who do not have confidence then become convinced and can achieve learning goals. This is done by inserting positive words, and the teacher also shows supportive body gestures by giving a thumbs up and making physical contact such as stroking his head or tapping his shoulders. This will stimulate students' enthusiasm for learning. The teacher's job is not easy to increase self-confidence.

The role of the SDLB B Kranji teacher is to provide constructive advice or messages. The teacher also conveyed that in offering guidance to students again using concrete examples, this was done to understand students with special needs directly, for instance, in the form of audiovisuals such as videos of successful figures or figures with disabilities who have succeeded. This will increase students' confidence that each individual has and can do everything, and when they have a sense of will and trust in their self-potential or self-concept, it grows. This method can inspire all students to be more enthusiastic in carrying out their duties and study more actively to achieve their dreamed goals. This is in line with the opinion according to [18] that the role of the teacher as an educator is a role related to the tasks of providing assistance and encouragement (supporter), the study of supervising and coaching (supervisor), and increasing student self-confidence to be suitable for student involvement in the learning process. The principal also explained how to guide each teacher. Differently, this is because each teacher needs to adjust to the character of students with special needs who will be mentored. The class teacher considers different names in handling guidance optimally to achieve learning goals. The principal prepares plans to implement guidance and counseling services for students with special needs as character building. This is in line with [19] that counseling guidance services aim to plan study completion activities, career development, and life development in the future and then develop them to adapt to the educational environment, community environment or work environment and be able to cope with obstacles and difficulties faced in learning.

Increasing students' self-confidence can also be done through competition activities between schools or classes. The teacher gives students guidance in competition activities. This needs to be done so that students are brave and confident to make works of art and even appear 
in front of many people. The teacher said that increasing students' self-confidence was by fostering or guiding both in learning and in competitions. According to [6], this is in line with the opinion regarding self-confidence, which is a mental attitude of optimism from students' ability to solve everything and their ability to make adjustments to the situation at hand.

\subsection{The Role of Classroom Teachers in the Implementation of Guidance and Counseling in Forming Discipline Character}

The classroom teacher's role is to provide subject matter and gives counseling guidance to students with special needs. Implementing counseling guidance services at SDLB B Kranji is critical, especially in fostering disciplinary attitudes for students with special needs. Teachers have a big responsibility in promoting student discipline so that students can obey the rules that apply in school. The field is essential and needed by students with special needs to comply with applicable regulations.

The principal is involved in dealing with students with special needs who violate school rules. The efforts to foster student discipline that have been carried out by school principals and teachers are proven by students who have complied with school rules, wear uniforms according to their schedules, come to school on time, do homework, enter class on time, and do not skip truancy. The teacher will punish the violation of discipline. Punishment is given by students so that students don't repeat the same mistakes. A teacher's warning so that students do not violate the rules and students do not repeat their mistakes. School rules are made so that students have an awareness that it is essential to have good discipline. In line with [20] opinion, the field is the awareness and willingness within oneself to comply with applicable rules, not pressure from outside. Changes in disciplinary attitudes include actions taken by the teacher, such as being reprimanded, advised, even punished to comply with the rules that apply in schools. This is in line with [21], arguing that indicators of disciplinary attitude include: 1 . Attendance of students at school. The presence of students at SDLB B Kranji was on time. Although there are still some students who sometimes are still not on time. 2. Dress neatly and entirely in uniform. Based on interviews with students, students have worn school uniforms according to their schedule because it is part of school rules that must be obeyed. 3. Obey the school and class laws. 70\% of students have an excellent disciplined attitude, which means they have followed the rules in school.

Fostering a disciplined attitude in elementary schools, of course, cannot be separated from the school in making changes [22]. Discipline is not only in coming to school on time, wearing uniforms according to schedule, doing homework, and not skipping school. But the field in the religious side can also be done simultaneously, such as discipline in memorizing short letters. This activity is so that students have the responsibility to learn. The implementation of counseling is carried out from grade 1 to grade 6 and is handled directly by each class teacher. Counseling guidance is carried out not only for students with special needs who experience problems but also for students who excel and receive advice. The implementation of counseling guidance services uses different methods and methods. Judging from the issues that occur and student characteristics first. The problems that occur are not always the same, and students who have problems are not the same. Therefore, each class teacher uses their ways of dealing with students. Guiding students with special needs is not only in the academic section but also includes non-academics. The teacher carries out recommendations when learning occurs. If there are students who do not understand the material, the teacher repeats the material to understand it better. Providing advice when students are not doing homework so that students are motivated to be better. In the non-academic part of the competition, the teacher offers 
motivational guidance so that students want to take part in the contest and even get a winner. Guidance is given to all students in both classical and individual ways. Individual teacher guidance provides direction, advice, motivation, and is carried out outside teaching and learning activities. Classical or group guidance, namely, the teacher provides leadership, inspiration, and advice between lessons and outside learning in the classroom. In line with the opinion of [22], guidance is an effort made by mentors to direct individuals in a better direction to achieve optimal development.

Counseling is carried out to help solve problems in students who are truant or do not do homework. The teacher seeks information from the parents of students to find out why students are truant. Handling teachers to students who do not do homework, the teacher asks students to do it later after school. Counseling is handled by teachers in the teacher's room, classroom, and principal's office. Usually, students who experience problems are given reprimands, advice, and punishments that deter students. So that students have a good personality both inside and outside of school. In line with the opinion of [23] that the purpose of counseling is so that students avoid various problems, such as problems related to symptoms of mental illness (neurons and psychoses), social and spiritual, or in other words so that each individual has a healthy mind. One of them is by approaching and coaching students because of students' characteristics with special needs, how to handle it cannot be taken once but gradually and continuously. Students are made like friends so that students are open to the teacher. Make students comfortable with the teacher so that it is easier to find information from students. The implementation of counseling is supported by the collaboration of the school with the parents of students. The cooperation aims to make activities related to parents run well. Class groups forming social media groups to connect parents, students, and schools can be conveyed directly. Collaboration must be carried out so that school relations with parents and students can be well established.

\subsection{The Role of Class Teachers in the Implementation of Guidance and Counseling in Forming Achievement Motivation Characters}

The teacher has an essential duty to guide and motivate, such as giving encouragement to students, creating a pleasant atmosphere while learning takes place, and giving praise. The teacher is also a facilitator for students to form a character of achievement motivation both in the academic and non-academic fields. The teacher has a big responsibility, namely the teacher's role in educating and guiding, but the teacher must provide an excellent example to students so that students have moral values, discipline time by leaving school on time, dressing neatly, and not violating existing regulations. School. In addition to providing learning to students, class teachers also have a role in familiarizing and providing good things for students, such as giving advice and guidance that fosters student enthusiasm and creates a suitable environment for students to behave and behave according to their age. Teachers always guide and support students to achieve achievements in both academic and non-academic fields. The teacher is very kind and teaches patiently so that students understand and understand the learning given.

Guidance and counseling can help students solve a problem they face to provide a change and sound development. The teacher offers individual guidance and counseling by maintaining the confidentiality of the issues and providing solutions for students in separate rooms where no one else is on for breaks or from school. The teacher provides guidance and counseling classically between lessons by dividing the group of teachers into each group to ask about students' difficulties to be adequately resolved. After learning is complete, the teacher evaluates the teaching that has been passed. The implementation of guidance and counseling is carried out by the classroom teacher as a whole. Guidance and counseling services are provided 
classically in between lessons by dividing groups of students in each class. These activities can make students develop better individually with students who have low achievement motivation or are included in the slow learner category. As with the opinion of [24] argues that guidance and counseling are assistance services for students, both individually and in groups to be independent and develop optimally, in personal direction, social advice, study guidance, and guidance. careers, through various types of services and support activities, based on prevailing norms. Guidance and counseling really help students with special needs in solving a problem in learning such as being afraid to ask material that students do not understand, or when students online classroom teacher as a whole carries out the implementation of guidance and counseling teacher always gives direction, feels comfortable and confident in every lesson to students with special needs by clapping, singing together, games by linking learning, and quizzes with prizes students' enthusiasm for learning. Students are not afraid to ask the gain with the teacher's al. ys trying to answer questions from students with full confidence and tenderness to understand and grow high motivated, ion to achieve achievement.

Researchers at SDLB B Kranji met character values that appear in guidance and careers for student achievement motivation. Students try to achieve achievements, seen from students always a long time, completing assigned assignments on time, following school regulations, accepting appointments that the teacher gives with enthusiasm and not being overwhelmed, being active when learning takes place, often participating in competitions in the field academic and non-academic with full confidence, and enthusiasm for learning by doing additional lessons to be able to beat other schools. This is following [25] argues that achievement motivation is manifested in students' driving force to seek progress in learning and pursue maximum levels of achievement self-enrichment and self-respect. The teacher guides in learning to foster student achievement motivation by showing a competition video that seniors participated in so that students with special needs are motivated to participate in the competition by honing students' abilities in the academic field.

Students who take part in competitions have a more mature experience than other students. The sense of pride from teachers and parents can also make students with special needs very proud and happy about the hard work that these students do in participating in the competition. The awarding of awards is in the form of certificates and trophies from several battles that have been experienced and won. The cup is placed in a glass cabinet to be seen by the students to motivate them to achieve. The school principal also always supports students by becoming facilitators, providing space for training, providing the needs needed in competitions in the form of material that students need to learn for the competition, and preparing the administration required for the competition. So that students only focus on participating in a battle to get a champion. This is to motivate students with other special needs to join in achievements such as other friends who have participated in competitions with enthusiasm for learning, do assignments well, work on practice questions for matches prepared by teachers, study groups, and set targets. achievement for students to achieve the desired achievement. [22].

\section{Conclusion}

SDLB B Kranji teachers provide counseling guidance services through responsive services and support services. Teachers provide responsive services that require immediate guidance. SDLB B Kranji teachers provide responsive advice when learning occurs in class, not to be left 
behind in lessons. Support services are used by SDLB B Kranji teachers because there are no special learning hours for counseling so that class teachers can guide learning to students.

Character building in elementary schools is significant because students begin to form characters such as caring for fellow friends, behaving politely to teachers, school principals, and older people, especially students with special needs. Character building in students with special needs at SDLB B Kranji is carried out in every subject, not only in Civics and Religion learning. The teacher provides examples by relating to the material being taught so that students can follow well. Character education is an effort to instill good habits so that students with special needs can behave and act based on the values that have become their personalities.

\section{References}

[1] Minsih. (2015). Implementation of Basic Guidance Services in Shaping Student Character at Muhammadiyah Elementary School, Surakarta City Special Program. Journal of Basic Education Professions, 2, (2), 112-120.

[2] Wiliandani, AM, Bambang, B.W., and A. Yusuf. (2016). Implementation of Character Education in Learning in Elementary Schools. Journal of Humanities Education. Vol 4 No 3: 132-142.

[3] Martini, Eneng. 2018. Building the Character of the Young Generation through the 21st Century SkillsBased Learning Model. Pancasila and Citizenship Journal. Vol, (3). Number 1). pp. 21-27.

[4] Nasuha, Ismail R., et al. 2019. Building Character Through the Implementation of Behaviortic Learning Theory of Mathematics Learning Based on 21st Century Skills. Menara Ilmu. Vol, (13). pp. 76-88.

[5] Sholichah, USA. (2018). Educational Theories in the Al-Qur'an. Journal of Islamic Education. Vol 7 No 1: 23-45.

[6] Ayu, S Nanda. 2017. Character Education As A Pillar Of Nation Character Building. National Seminar Proceedings. Vol, (1). Number 1). pp. 348-352.

[7] Syarif I, et al. 2017 Implementation of Problem Based Learning in Class IV Social Studies Subjects' Learning Outcomes. Journal of Education. 1, (1), 48-60.

[8] Amani. 2018. The Role of Guidance and Counseling in Student motivation at SMP N 15 Yogyakarta. Journal of Islamic Counseling and Da'wah Guidance. 15, (1), 20-34.

[9] Nurmalasari, F., Siagian, S., \& Mursid, R. (2019). The Influence of Learning Strategies and Achievement Motivation on Indonesian Language Learning Outcomes. Journal of Educational Technology (JTP), 12 (2), 126-139.

[10] Suradi. (2017). The formation of student character through the application of disciplinary rules. Journal of Research and Conceptual. Vol 2 No 4: 522-533.

[11] Nurlaily, A., 2019. Guidance and Counseling in Elementary Schools: Class Teachers Play an Important Role in Service Implementation. Belaindika Journal. 1, (2), 12-19.

[12] Kumala, S Nova. 2019. The Influence of Discipline, Confidence, and Mathematical Logical Intelligence on Student Mathematics Learning Outcomes. Journal of Pythagoras. Vol, (8). Number 1). pp. 49-59.

[13] Putri W, Ika. 2019. Mathematical Critical Thinking and Student Confidence in terms of Advertise Quotient. PRISMA, Proceedings of the National Mathematics Seminar. ISSN 2613-9189. pp. 629636.

[14] Fifi W, Iga., Et al. 2017. The tendency of the quality of self-confidence of fifth-grade students of SD Negeri 2 Sukasada, Buleleng district. Journal of Elementary School Education. Vol, (5). No, (2). Pp. $1-10$.

[15] Bangkit, K Indra. 2016. The Relationship Between Self Confidence and Student Achievement and Career Planning. Psychopedagogy. Vol, (5). Number 1). pp. 33-42.

[16] Uci, K. and et al. (2020). The Role of Classroom Teachers as Counseling Guidance Service Implementers in Fostering Self-Confidence and Learning Achievement of Students at SD Negeri 1 Srowot. Journal of Education and Development. Vol. 8. No.3

[17] Hayati, Fitri. 2016. The Role of Guidance and Counseling Teachers in Overcoming Aggressive Tendencies of Students in M.A. Journal of Education Managers. Vol, (10). No, (6). HTML 603-607. 
[18] Junji. 2016. The Urgent Role of Teachers in Education. Scientific Journal of Education. Vol (10) No (1). pp. 52-62.

[19] Rizki P, Amalia. 2017. The Concept of Technology in Counseling Guidance. Journal of Islamic Education Management. Vol, (5). No, (2). pp. 1-12.

[20] Haryono, S. (2018). The Effect of Student Discipline and Learning Motivation on Student Achievement in Economics Subjects. Educational Scientific Journal Factors. Vol 3 No 3: 261-274.

[21] Indrawati I and Ali M. (2013). Improving Student Discipline Behavior Through Reward and Punishment Learning in Physical Education Learning for Class XII IPS 1 Student at SMA Negeri 1 Lamongan. Journal of Sports and Health Education. Vol 01 No 02: 304-306.

[22] Oktrinita, L and et al. (2020). The Role of Classroom Teachers in the Implementation of Guidance and Counseling in Building Character and Student Achievement Motivation at SD Negeri 8 Kranji. Wahana Pendidikan Scientific Journal. Vol. 6. No. 3.

[23] Nasution H \& Abdillah. 2019. Counseling Guidance "Concept, Theory and Application." Medan: LPPPI.

[24] Prasetiawan, H. (2016). The Role of Guidance and Counseling in Child-Friendly Education on Character Building from Early Age. CARE Journal (Children Advisory Research and Education). Vol 4 No 1: 50-60.

[25] Oktasari, M. (2019). Contribution of Study Habits to Student Achievement Motivation and Its Implications in Guidance and Counseling Services. Journal of Counseling and Education Studies, 2, (3), 117-123. 